\title{
Studying the effect of potato products in extending the period of potato storage
}

\author{
Nasiba Ibragimova ${ }^{1, *}$, Sayyora Murodova ${ }^{2}$, Denis Otanazarov $^{1}$, and Mutabar \\ Khojanazarova $^{1}$ \\ ${ }^{1}$ Urgench State University, Hamid Alimjan str., 14, Khorezm, Uzbekistan \\ ${ }^{2}$ Tashkent State Agrarian University, Universitetskaya str., 2, 100140, Tashkent, \\ Uzbekistan
}

\begin{abstract}
In this research, the cultivation and storage of potatoes grown in saline soils of Khorezm region at different levels with biopreparations, such as Bist (Pseudomonas putida) and Zamin-M (Bacillus subtilis, Bacillus megaterium and Pseudomonas stutzeri), were studied. In the experimental variants, there was $1.381 \mathrm{mg} / \mathrm{kg}$ of vitamin $\mathrm{C}$, followed by $0.112 \mathrm{mg} / \mathrm{kg}$ of vitamin $\mathrm{B}_{6}, 0.089 \mathrm{mg} / \mathrm{kg}$ of vitamin $\mathrm{PP}, 0.481 \mathrm{mg} / \mathrm{kg}$ of vitamin $\mathrm{B}_{12}$ and $0.092 \mathrm{mg} / \mathrm{kg}$ of vitamin $\mathrm{B}_{2}$ when Zamin-M was applied. Potatoes, which were treated with Zamin-M, contained $0.45 \%$ Fructose, $0.87 \%$ Glucose, $0.92 \%$ Sucrose, $0.04 \%$ Maltose, and it was higher than other biopreparations. During storage, the number of diseased nodules was $21.8 \%$ when treated with Earth ointment, it was $20 \%$ when treated with Bist, and it was $19.8 \%$ when treated with Zamin-M. The results showed that Zamin-M was suitable in soil and climate conditions of Khorezm region, especially for storage of potato, and it was found that Zamin-M contained microorganism, which activate the synthesis of phytohormones operating under stress. In comparison, the tested Zamin-M extended the shelf life of potatoes by $25 \%$ than the control variants.
\end{abstract}

\section{Introduction}

More than 290 million tons of potatoes (Solanum tuberosum) are produced worldwide every year. According to FAO 2004-2005 statistics, China, Russia, India, Ukraine and the United States ranked in between 1st and 5th in terms of potato cultivation, respectively. Potato cultivation ranks fourth among agricultural crops after wheat, corn and rice $[1,3,4]$. Potatoes are an important crop that promises food to millions of people, especially in developing countries. Some tuber diseases, such as dry rot, appear mainly in storage, while others, such as mild rot, affect the potato root at every stage. The main fungal and bacterial diseases affecting the potato crop are considered here by their identification, symptoms on the potato plant or rhizome, the nature of the pathogen, epidemiology, control measures, and other factors [4]. Potatoes can be affected by many diseases that affect the pre- and post-harvest stages of the crop. The main fungal diseases affecting the crop are late blight,

*Corresponding author: muminovna83@mail.ru 
early blight, black scurf, fusarium dry rot, wart, powdery mildew and charcoal rot. Such diseases are common in many countries and can lead to a significant decrease in potato production $[5,8,9]$. Furthermore, salt resistance of plants is a large and multifaceted problem. Salts increase the osmotic pressure of the soil solution, thereby making it difficult for plants to get water (physiological shoreline) and access to water and nutrients (salt depletion). Many salts alter the metabolism and allow plants to accumulate toxic byproducts, which in turn leads to salt poisoning, which affects the accumulation of chlorophyll, resulting in the loss of some parts of the leaf. It becomes incapable of accumulating organic matter $[2,5]$. Other changes are observed in the plant: a decrease in tissue moisture, loss of growth points, increasing necrosis, and others. As the temperature rises, the toxicity of the salts increases. Compression of plants in saline soils depends not only on the presence of salt in the soil, but also on the composition of salts in them. Salinization of plants with chlorinated salts creates worse conditions for their growth than sulfate salinity, less organic matter accumulates, and plants become much smaller [11, 12].

The agro-industrial complex and its basic branch is the leading system of agriculture sector of the Uzbekistan economy. One of the developing directions of agriculture is potato growing. However, there are some barriers in potato growing: the need for producers of imported varieties, inconsistencies in agro-climatic and soil conditions of the country's plans, high level of loss of seed materials, loss of varieties, their economic value, outdated material and technical base, production low renewal of production technology and storage, high level of environmental burden on agroecosystem $[6,7,11]$. Local manufacturers are abandoning outdated and ineffective technologies and introducing new scientific methods that have been tested. Potatoes were brought to Uzbekistan in the second half of the 19th century. After the adoption of the Resolution of the Cabinet of Ministers of the Republic of Uzbekistan No. 301 of August 30, 1996 "On measures to deepen market relations in potato growing and increase potato production in the country", the gross potato yield was 692,000 tons, potato production was reached $30 \mathrm{~kg}$ per capita in 1997, and the import of potatoes was stopped.

The presence of a complex of nutrients such as starch, protein, non-protein nitrogen compounds, soluble carbohydrates, minerals and lipids (fatty substances) in the potato pulp ensures its high nutritional value. Potato tuber contain small amounts of pectin, vitamins, alkaloids and other compounds that affect its nutritional and taste quality $[10,13,17]$. The sugar content of potatoes is mainly in the form of glucose, while sucrose and fructose are present in very small amounts. The high content of sugar in the potato tuber has a negative effect on its taste. Because when the tuber is processed, the sugar dissolves quickly, reacts with substances formed by the breakdown of protein, giving it a dark brown color, and reduces the quality [3, 5-9]. The amount of sugar in the tuber depends on the variety of potato and its degree of maturity. Unripe young tubers contain more sugar than the ripen ones. When stored in a slightly cold place, the sugar content increases. Moreover, it was found that tuber contained more than 200 mineral elements. The ash (mg per $100 \mathrm{~g}$ of raw weight) contains potassium -568, phosphorus -58 , calcium -15 , chlorine-50, and magnesium-45. They contain small amounts of iron, copper, manganese, sodium, cobalt, sulfur, silicon and other similar mineral elements [2, 8, 9].

Leaves of cherries, currants, sweet peppers and greens are rich in vitamin C. However, if people consume 300 grams of potatoes, they may provide the body with two thirds of the amount of vitamin $\mathrm{C}$ required per day, $17.5 \%$ of vitamin $\mathrm{B}_{1}$ and $5 \%$ of vitamin $\mathrm{B}_{2}$. During the winter storage of tubers, the content of vitamins is reduced by 2-3 times, and peeled potatoes lose $25 \%$ of vitamin C, whereas not peeled may lose $20 \%$ of vitamin content. It is advisable to apply mineral fertilizers in the right proportions to reduce the darkening of the potato flesh $[5,6,9,15-17]$. The mechanical composition of the tubers increases the darkening of the potato flesh when grown in heavy soils with high nitrogen and chlorine 
fertilizers $[9,11]$. However, it was stated that the country still was faced some issues in the production of highly quality and nutritious potatoes, and the prolongation of the storage period of potatoes. Therefore, this research was aimed at determining ways of increasing productivity and marketability; create environmentally safe and cost-effective production of potatoes by improving the technology of storage and reducing pathogen contamination during storage in Khorezm region.

\section{Materials and methods}

Inoyat-Jumaniyaz farm of Urgench district, Khorezm region was selected as study site, where the cultivation and storage of potatoes were grown in saline soils of Khorezm region at different levels of bio-preparations, such as Bist (Pseudomonas putida) and Zamin-M (Bacillus subtilis, Bacillus megaterium and Pseudomonas stutzeri), were studied. Biopesticides or biological pesticides involve the use of living biological organisms or their metabolites for pests, pathogens, weeds, nematodes, rodents, and more [11-12, 14]. According to FAO standards, bio-pesticides are defined as typically natural compounds or means of genetic modification, including biochemical pesticides (pheromones, hormones, plant regulators, insect growth regulators) and microbial pesticides (fungi), bacteria or genetically modified microorganisms) do not contain antibiotic agricultural preparations. Samples were evaluated at the Institute of Bioorganics, and the High-Performance Liquid Chromatography (HPLC) were employed to detect water-soluble vitamins [5, 7-9]. Following conditions for chromatographic analysis were considered: moving phase (gradient mode) - acetonitrile buffer solution $\mathrm{pH}=2.92$ (4\%: 96\%) 0-6 minutes, (10\%: 90\%) 6-9 minutes, (20\%: 80\%) 9-15 minutes, (4\%: 96\%) 15-20 minutes. Injection volume is $20 \mathrm{ml}$, followed by the speed of the moving phase is $1,000 \mathrm{ml} / \mathrm{min}$, Column-Eclipse XDB-C18, detector diode-matrix, wavelength is 272, 292, 254, 297 and $360 \mathrm{~nm}$, and Dry Residue, such as Governmental Standards 26712-85 and 26718-85.

\section{Results and discussion}

The results of the experiment showed that potatoes contained varieties of vitamins in per 100 grams of raw mass, such as RR-0,04-2,0, $\mathrm{V}_{1}-0,05-0,12, \mathrm{~V}_{2}-0,01, \mathrm{~V}_{6}-0,08-0,22, \mathrm{R}-3$ pantothenic acid, 0.2-0.3 carotene (vitamin A) - 0.05 , and small amounts of vitamins K, I, D, E. The amount of vitamin $\mathrm{C}$ was $10-30 \mathrm{mg}$, and even it was up to $50 \mathrm{mg}$. Evidently, immature young tubers were rich in vitamin $\mathrm{C}$. Table 1 showed that when the drug Zamin$M$ was used in the variant 1, vitamin $C$ was $1.381 \mathrm{mg} / \mathrm{kg}$, vitamin $B_{6}$ was $0.112 \mathrm{mg} / \mathrm{kg}$, vitamin PP was $0.089 \mathrm{mg} / \mathrm{kg}$, vitamin $\mathrm{B}_{12}$ was $0.481 \mathrm{mg} / \mathrm{kg}$ and vitamin $\mathrm{B}_{2}$ was 0.092 $\mathrm{mg} / \mathrm{kg}$, which were higher than other bio-preparations. The lowest indicators in vitamins were in potatoes in the variant 6 , where simple bio-preparation was used. Accordingly, vitamin $\mathrm{C}$ was $0.922 \mathrm{mg} / \mathrm{kg}$, followed by $B_{6}$ with $0.067 \mathrm{mg} / \mathrm{kg}$, PP with $0.039 \mathrm{mg} / \mathrm{kg}$ and $\mathrm{B}_{12}$ with $0.215 \mathrm{mg} / \mathrm{kg}$. 
Table 1. Vitamins of potatoes obtained under the influence of biological preparations.

\begin{tabular}{|c|c|c|c|c|c|c|c|c|c|c|c|c|c|}
\hline \multirow{3}{*}{ \# } & \multirow{3}{*}{$\begin{array}{c}\text { Sample } \\
\text { name }\end{array}$} & \multicolumn{12}{|c|}{ Identified concentrations } \\
\hline & & \multicolumn{2}{|c|}{$\mathbf{C}$} & \multicolumn{2}{|c|}{$\mathbf{B}_{6}$} & \multicolumn{2}{|c|}{$\mathbf{P P}$} & \multicolumn{2}{|c|}{$\mathbf{B}_{12}$} & \multirow{2}{*}{$\begin{array}{c}\mathbf{B}_{2} \\
\mathrm{mg} / \mathrm{k} \\
\mathrm{g}\end{array}$} & \multirow[b]{2}{*}{$\mathrm{mg} / \%$} & \multicolumn{2}{|c|}{$\mathbf{B}_{9}$} \\
\hline & & $\begin{array}{c}\mathrm{mg} / \mathrm{k} \\
\mathrm{g}\end{array}$ & $\mathrm{mg} / \%$ & $\begin{array}{c}\mathrm{mg} / \mathrm{k} \\
\mathrm{g}\end{array}$ & $\mathrm{mg} / \%$ & $\begin{array}{c}\mathrm{mg} / \mathrm{k} \\
\mathrm{g}\end{array}$ & $\begin{array}{c}\mathrm{mg} / \\
\%\end{array}$ & $\begin{array}{c}\mathrm{mg} / \\
\mathrm{kg}\end{array}$ & $\begin{array}{c}\mathrm{mg} / \\
\%\end{array}$ & & & $\begin{array}{l}\mathrm{mg} \\
/ \mathrm{kg}\end{array}$ & $\mathrm{mg} / \%$ \\
\hline 1 & $\begin{array}{c}\text { Zamin } \\
\mathbf{M}\end{array}$ & 1.382 & 13.81 & 0.112 & 1.12 & 0.089 & 0.89 & 0.481 & 4.81 & $\begin{array}{c}0.092 \\
0\end{array}$ & 0.93 & - & - \\
\hline 2 & $\begin{array}{c}\text { Earth } \\
\text { ointme } \\
\text { nt }\end{array}$ & 1.381 & 13.82 & 0.105 & 1.05 & 0.078 & 0.78 & 0.352 & 3.52 & 0.081 & 0.92 & - & - \\
\hline 3 & BIST & 1.325 & 13.25 & 0.081 & 0.81 & 0.081 & 0.81 & 0.234 & 2.34 & 0.80 & 0.81 & - & \\
\hline 4 & New & 1.273 & 12.73 & 0.076 & 0.76 & 0.033 & 0.33 & 0.132 & 1.32 & 0.093 & 0.80 & - & - \\
\hline 5 & Simple & 1.234 & 12334 & 0.072 & 0.72 & 0.024 & 0.24 & 0.113 & 1.13 & - & - & - & - \\
\hline 6 & Simple & 0.922 & 9.22 & 0.067 & 0.67 & 0.039 & 0.39 & 0.215 & 2.15 & - & - & - & - \\
\hline
\end{tabular}

The pertinent results depicted that Earth ointment was dominant in the dry residues, accounted for $25.11 \%$, whereas in higher moisture was observed when Zamin-M was used, which was $79.19 \%$. The lowest results in the residues and moisture were found in variant 5 , which were $21.21 \%$ and $75.47 \%$, respectively (Table 2).

Table 2. Effect of dry residue and moisture on potatoes under the influence of biological preparations.

\begin{tabular}{|c|c|c|c|}
\hline \multirow{2}{*}{$\#$} & \multirow{2}{*}{ Sample name } & \multicolumn{2}{|c|}{ Identified concentrations \% } \\
\cline { 3 - 4 } & & Dry residues & Moisture \\
\hline 1 & Zamin-M & 24.53 & 79.19 \\
\hline 2 & Earth ointment & 25.11 & 78.79 \\
\hline 3 & BIST & 23.92 & 76.53 \\
\hline 4 & New & 23.47 & 76.08 \\
\hline 5 & Simple & 21.21 & 75.47 \\
\hline
\end{tabular}

Table 3 presented that fructose content in potatoes planted using Zamin-M was $0.45 \%$, glucose was $0.87 \%$, sucrose was $0.92 \%$ and maltose was $0.04 \%$, and this variant was found to have a higher rate than Bist, Earth ointment, new medicine, and impact of biopreparations on potato crop productivity during storage in 2019-2020 year.

Table 3. The effect of potatoes on carbohydrates obtained under the influence of biological preparations.

\begin{tabular}{|c|c|c|c|c|c|}
\hline Types & №1 & №2 & №5 & №4 & №5 \\
\hline Fructose & 0.45 & 0.00 & 0.00 & 0.00 & 0.00 \\
\hline Glucose & 0.87 & 0.01 & 0.00 & 0.00 & 0.00 \\
\hline Sucrose & 0.92 & 1.28 & 0.71 & 0.52 & 0.32 \\
\hline Maltose & 0.04 & 1.39 & 1.33 & 0.76 & 0.55 \\
\hline
\end{tabular}

During the storage period, the incidence was $21.8 \%$ when treated with Earth ointment, followed by $20 \%$ when treated with Bist, and $19.8 \%$ when treated with Zamin-M. Consequently, Zamin-M and its different concentrations were used towards prolonging the shelf life of potatoes (Table 4). 
Table 4. Infected potatoes in different variants.

\begin{tabular}{|c|c|c|}
\hline Variants & $\begin{array}{c}\text { The number of } \\
\text { infected potatoes }\end{array}$ & $\begin{array}{c}\text { Infected potatoes } \\
\text { \% }\end{array}$ \\
\hline Control & 246 & 24.6 \\
\hline Earth ointment & 218 & 21.8 \\
\hline Bist & 20 & 20 \\
\hline Zamin-M & 198 & 19.8 \\
\hline
\end{tabular}

When studying the effect of different concentrations of Zamin-M biopreparation on the storage period of potato tubers, pre-storage treatment with concentrations in the ratio was 1 : $100,1: 500$ and 1:1,000, respectively, whereas productivity was 96.7\%, 97.3 and 100\%, respectively. In the control variants, the lowest productivity was observed, accounted for $93.7 \%$, due to $6.03 \%$ infected tubers (Table 5 ).

Table 5. Effect of different concentrations of Zamin-M on the shelf life of potato tubers.

\begin{tabular}{|c|c|c|}
\hline Experimental variants & $\begin{array}{c}\text { The amount of infected } \\
\text { tubers \% }\end{array}$ & Productivity \% \\
\hline $1: 100$ & 3.3 & 96.7 \\
\hline $1: 500$ & 2.7 & 97.3 \\
\hline $1: 1000$ & - & 100 \\
\hline Control & 6.03 & 93.7 \\
\hline
\end{tabular}

\section{Conclusions}

Khorezm region was suitable for soil climatic conditions during storage of potato crop from Zamin-M preparations, which was explained by the storage of microorganisms that activate the synthesis of phytohormones operating under stress. The drug "Zamin-M" was used to extend the shelf life of potatoes by $25 \%$ compared to control options. It was stated that as the salinity of the soil was increased, the dry matter and starch content of the tuber was decreased significantly, and the amount of ash and chlorine increases, especially in the leaves and stems. The reason for the decrease in the amount of starch in the tuber was that chlorine ions had the property of reducing the starch, as well as the flow of the smallest grains of starch from the leaf to the tuber.

The number of plants was reduced when the tubers grown in saline soil conditions were planted in fresh and saline soils. The yield of potato varieties grown in saline soils depends not only on their resistance to salt, but mainly on their resistance to early ripening and nausea. The harvesting phase of potatoes planted in early spring coincided with the period when the air temperature rises and salt accumulates in the soils. Therefore, it was advisable to plant the earliest varieties during this period. The growth and development of potatoes planted in the summer coincided with a period of temperature drop, so if high-yielding and disease-resistant late varieties were planted, their tuber formation phase coincides with the cool days of autumn.

\section{References}

1. G. Yu. Rabinovich, Yu. D. Smirnova, N. G. Kovalev, Russian Agricultural Sciences, 42 (2016) 
2. S. Isaev, S. Khasanov, Y. Ashirov, T. Karabaeva, A. Gofirov, In E3S Web of Conferences, 244, 02012 (2021)

3. I. Novikova, Yu. D. Shenin, Applied Biochemistry and Microbiology, 47 (2011)

4. V. K. Chebotar, N. M. Makarova, Applied Biochemistry and Microbiology, 6 (2009)

5. S. Shakouri, H. Ziaolhagh, J. Sharifi-Rad, M. Heydari-Majd, R. Tajali, S. Nezarat, J. Da Silva, Journal of Food Science and Technology, 52, 6 (2015)

6. H. Gao, Q. Zeng, Z. Ren, P. Li, X. Xu, Journal of food science and technology, 55, 12 (2018)

7. Y. Peng, F. Li, N. Xu, R. Kulmatov, K. Gao, G. Wang, Y. Zhang, Y. Qiao, Y. Li, H. Yang, S. Hao, Q. Li, S. Khasanov, Chinese Journal of Eco-Agriculture, 29(2), 312-324 (2021)

8. S. Isaev, S. Khasanov, Y. Ashirov, A. Gofirov, T. Karabaeva, In E3S Web of Conferences, 244, 02047 (2021)

9. N. Teshaev, B. Mamadaliyev, A. Ibragimov, S. Khasanov, InterCarto. InterGIS, 26(3), 324-333 (2020)

10. R. A. Kulmatov, S. A. Adilov, S. Khasanov, In IOP Conference Series: Earth and Environmental Science, 614(1), 012149 (2020)

11. O. Lastochkina, A. Baymiev, A. Shayahmetova, D. Garshina, I. Koryakov, I. Shpirnaya, R. Palamutoglu, Plants, 9, 1 (2020)

12. M. Kammoun, M. Essid, F. Ksouri, V. Rokka, M. Charfeddine, R. Gargouri-Bouzid, O. Nouri-Ellouz, Journal of Plant Physiology, 254 (2020).

13.L. Ren, T. Zhang, H. Wu, Y. Ge, X. Zhao, X. Shen, A. Wang, Journal of Food Processing and Preservation, 45, 2 (2021)

14. A. Goyer, M. Picard, H. Hellmann, S. Mooney, Journal of the Science of Food and Agriculture, 99, 10 (2019).

15.I. Sugri, B. Maalekuu, E. Gaveh, F. Kusi, S. Lamini, Sustainable Agriculture Research. 9, 4 (2020)

16. M. Alamar, R. Tosetti, S. Landahl, A. Bermejo, L. Terry, Frontiers in plant science, 8, (2017)

17.C. Ji, W. Chung, H. Kim, W. Jung, L. Kang, J. Jeong, S. Kwak, (2017). Plant Physiology and Biochemistry, 112 (2017) 